\title{
The Effect of Tourists' National Culture on Perceived Performance of Restaurants in Petra, Jordan
}

\author{
Ma'moun A. Habiballah ${ }^{1}$, Jebril A. Alhelalat ${ }^{1} \&$ Naseem M. Twaissi ${ }^{2}$ \\ ${ }^{1}$ Department of Hotel and Tourism Services Management, Petra College for Tourism and Archaeology, \\ Al-Hussein Bin Talal University, Jordan \\ ${ }^{2}$ Department of Business Administration, Faculty of Business Administration and Economics, Al-Hussein Bin \\ Talal University, Jordan \\ Correspondence: Jebril A. Alhelalat, Department of Hotel and Tourism Services Management, Petra College for \\ Tourism and Archaeology, Al-Hussein Bin Talal University, Jordan. Tel: 962-32-155-415. E-mail: \\ jebrilalhelalat@gmail.com
}

Received: December 17, 2015

Accepted: January 8, $2016 \quad$ Online Published: February 25, 2016

doi: 10.5539/ibr.v9n3p25

URL: http://dx.doi.org/10.5539/ibr.v9n3p25

\begin{abstract}
The primary aim of this research is to study the influence of customers' national culture on Perceived Performance of Restaurant Services (PPRS) in Petra city. Restaurant service quality links to server behavior in relation to customers' cultural background were researched thoroughly considering the attributes of servers' accommodation, sanitation, product knowledge, entertainment, professionalism, and cordiality. The present research was carried out using a self-administrated questionnaire which was surveyed on 155 tourists from different nationalities. Results of data analyses applied in the current study support the impact of national culture on tourists' PPRS. The culture influence was significantly direct on some of the service quality factors (entertainment, sanitation and product knowledge) and indirect on other factors (professionalism, accommodation and cordiality). A detailed explanation was provided in the present study to contribute in wider understanding of how national culture and its dimensions may shape the perceptions of food service quality.
\end{abstract}

Keywords: customer perceptions, national culture, perceived performance, Petra, restaurants, service quality

\section{Introduction}

Based on the nature of service as intangible, variable, perishable, and inseparable, it is difficult to assess the perceived service without considering the service customer characteristics; Kotler and Keller (2012) emphasize that companies must manage service quality by understanding each service customer. They state that there is a need for both internal and external marketing to emphasize the importance of the employee role and customer role in service marketing. In addition, there is a great emphasis on the role of employee in understating service customer and in delivering quality service that enhance customer satisfaction (Kusluvan, 2003; Zhang, 2008; Brown \& Lam, 2008). In the restaurant industry, the literature is rich of research that apply different service quality techniques; it supports that customers have high standards and demands for quality service through the selection of restaurants that meet their quality and value standards (Rao \& Sahu, 2013; Kariru \& Aloo, 2014).

\subsection{Research Background}

Service quality is one of the managerial functions that interrelate with different aspects inside the organization. The importance of studying service quality in service businesses stems from the fact that service quality leads to customer satisfaction and has a positive impact on customer word-of-mouth, loyalty, and purchase intentions (Carrillat, Jaramillo, \& Mulki, 2007). Moreover, Manhas, and Ramjit (2011) stress on the fact that service quality has a positive impact on areas within the organization such as employee morale, reduction in costs and waste, and time management. Parasuraman, Zeithaml, and Berry (1988) define service quality as the discrepancy between consumers' perceptions of services offered by a particular firm and their expectations about firms offering such services.

Customers assess service quality and service value through a comparison between anticipated and perceived performance levels. In other words, customers' expectations, perceptions of current performance, and disconfirmation experiences affect their satisfaction or dissatisfaction with a service and hence, their assessment 
of service experience (Bolton \& Drew, 1991). Gagic, Tesanovic and Jovicic (2013) consider the nature of the relationship between customer satisfaction and service quality. They state that perceived quality is one of the core determinants of overall satisfaction; it is generally assumed that deliv-ering high-quality service will lead to satisfied customers. Customer satisfaction is an individual's feeling of pleasure or disappointment resulting from comparing a product's perceived performance in relation to his or her expectations (Fen \& Lian, 2005).

Parasuraman et al. (1988) view expectations and perceived service performance as "desires or wants of consumers". According to the American Marketing Association, perception is the cognitive impression that is formed of "reality" which in turn influences the individual's actions and behavior toward that object. In addition, perceived quality is the overall subjective judgment of quality relative to the expectation of quality (Mitra \& Peter, 2006).

Customers hold different types of expectations about service, the highest type of these is desired service (the level of service the customer hopes to receive) and adequate service (the service would not always be performed according to their expectations) (Zeithaml, Bitner, \& Gremler, 2009). The expectations signal the level of customer hopes and wishes and beliefs that they may be fulfilled (Phiri \& Mcwabe, 2013). Accordingly, service quality should be measured using performance-based measures (Johnston, 1995).

Customer-employee interaction is another important factor here; it was found that the link between customer experience and employee performance and interaction in a service quality context is evaluated through the service quality measures of care, honesty and the quality of interaction and communication process (McCain, Jang \& Hu, 2005). The quality of interaction is part of the quality of service in the face-to-face types of services; $\mathrm{Wu}$ and Liang (2009) state that the interactive relationship between consumers and service employees is important to consumer evaluations; specific behaviors, including the behavior of service employees, are key determinants of perceived service quality.

Parasuraman et al. (1988) find that five dimensions are associated with customers' satisfaction and their perceptions of service quality; tangibles (physical facilities, equipments, appearance of personnel), responsiveness (willingness to help customers and provide prompt service), reliability (ability to perform the promised service), assurance (knowledge and courtesy of employees and their ability to inspire trust) and empathy (caring, individualized attention the firm provides to customers) are the main dimensions in their SERVQAL model. Becker, Murrmann and Cheung (1999) argue that when discussing the appropriateness of the SERVQUAL to the particular needs of hospitality providers, additional concerns were directed toward three major issues: Level of measure (service encounter and face-to-face nature of hospitality services), equivocality of measures, and social orientation (service is social transactions between service customers and service providers).

It was highlighted through the literature that the level of service quality can be greatly improved by enhancing the behaviors and attitudes of staff; employees' responsiveness and willingness to provide services, and their ability to adapt to customers' demand (Kuo \& Hsiao, 2013). Therefore, there is a great focus on the employees' role in overall perception of service quality. Within this context, Akbaba (2006) find that an item called courtesy and competence of personnel is the most important attribute influencing the perception of quality within the hospitality sectors; including employee appearance, promptness of service, willingness to serve, availability when needed, occupational and specific product knowledge, friendliness, caring and giving individualized attention.

The hospitality industry, including restaurants, witnesses certainly an increased competition and rising consumer expectations of quality. Mei, Dean, and White (1999) conclude that service quality was represented by three dimensions in the hospitality industry, relating to employees, tangibles and reliability; the most important of these is the dimension referred to as employees' behavior and appearance. Yoo (2012) support that in addition to the physical environment and hygiene of the restaurant facilities, employee appearance and behavior (personal hygiene, food handling behaviour, health condition, and multi-skilling) is important in the view of restaurant customers in the evaluation of service quality.

Considering the specific measure of service quality in the restaurant business, Ha and Jang (2010) support that service reliability, service responsiveness, and service assurance are important measures of service quality in restaurants through the accurate delivery of quantity and quality promised, prompt and quick service, and employees' readiness to answer questions and demonstrate their knowledge. In addition, Gagic et al. (2013) analyze different service quality constructs in relation to restaurant business. They find that food quality, service quality (employees' willingness to help, employees' knowledge, staff appearance, atten-tive staff, and friendly dining managers), physical environment, and price fairness quality are the major determinants of restaurant 
service quality.

Becker et al. (1999) develop a set of items to measure service quality considering the nature of the hospitality industry and its universal context; those items are related to the behavior of food servers rather than the managerial process of quality assurance. They suggest accommodation (server's attentiveness to special needs), sanitation (server's cleanness of appearance and hygiene), product knowledge (server knowledge about menu items and ability to explain them), entertainment (server's friendliness and entertaining behavior), professionalism (server's demonstration of ability to interact with guests correctly and privacy respect), and cordiality (servers' smile, eye contact and comfortable manners).

Hence, the conceptual frame of service quality and service performance is widely studied (Parasuraman et al., 1988; Teas, 1993; Gronroos, 1994; Kang \& James, 2004; Kumar, Batista, \& Maull, 2011), however, Becker et al. (1999) allege for well identified, precise, actionable standards for measuring service performance in the cross-cultural context.

Carrillat et al. (2007) state that the validity of quality measures of services quality varies depending on different cultural contexts. This is because differences in national culture or language require a modification of their items and in how respondents perceive the model under investigation. Becker et al. (1999) reach results that support the assumption that customers' service expectations differ as a result of customers' cultural orientation. In addition, Furrer, Liu, and Sudharshan (2000) emphasize on the need to consider cultural and social aspects of customers when investigating their perceptions of service quality.

The work of the present study is believed to add to the body of research about tourists' perception of food service quality. It shed the light on cultural effects on tourists' perception within the Jordanian/Arabic service context. It was carried out in Jordan (a Middle Eastern country), where work-related practices are expected to be different from those taking place in the West. To the best of researchers' knowledge, this study can be the first one that explores cultural impact on tourists' perception of food service quality factors. The impact of culture on these factors might be established before in Becker et al. (1999) study. However, the reexamination of these factors increases their generalization and their usability in a worldwide manner.

\subsection{The Impact of Culture on Tourists' Perception}

It is believed that the growing trend of business activities and globalization provides an appealing reason for considering culture influence on consumers' behavior (Maheswaran \& Shavitt, 2000; Mooij, 2010). The true meaning of culture is still a matter of debate among scholars. According to Schneider and Barsoux (2003), anthropologists developed more than 164 definitions for culture. Nevertheless, due to the comprehensive and evolving nature of culture; it is still hard to propose an exact meaning of it. However, different definitions of culture revealed common facts about it; among others culture is a number of values shared within a group of people. One of the best known and most influential scholars in culture is Geert Hofestede. He defines culture as "the collective programming of mind" (Hofestede, 1980, p. 25). It was argued by Mwaura, Sutton, and Roberts (1998) that Hofestede's definition of culture is the most cited one in the literature. In view of that, Hofestede's definition was adopted in the present study.

Culture can be visualized as an onion. The core of this onion is composed of values, "the broad tendencies to prefer certain states of affairs over others", which are surrounded by layers of symbols, heroes and rituals. Those layers typify individual's practices that can be seen by outsiders; while their cultural meanings are inconspicuous and depend on interpretations of insiders (Hofstede \& Hofstede, 2005).

To achieve a better understanding of cultural meanings for different nations, some aspects of culture were developed into measurable dimensions (Hofstede \& Hofstede, 2005). Since fifty years, a large number of national culture dimensions have been developed by many sociologists, anthropologists and social-psychologists (Pizam, 1993). Among these dimensions, Hofestede's dimensions were used as a paradigm in 274 cases within different disciplines (Søndergaard, 1994). Till these days, Hofestede's cultural dimensions are still used by many researchers including Humphreys (1996), Harvey (1997), Schermerhorn and Bond (1997), Furrer et al. (2000), Robins and Stylianou (2001), Chang (2003), Kanousi (2005), M. Tawakoli and A. Tawakoli (2010), Park (2011), Baker, Meyer, and Chebat (2013) and Mazanec, Crotts, Gursoy, and Lu (2015). Such intensive and continuous use of Hofestede's dimensions shows the reliability, validity and importance of Hofestede work in understanding culture and its impact on human practices.

Based on different studies, Hofestede (1980, 1991, \& 2001) identify, in an empirical manner a group, of national cultural dimensions. These are Individualism vs. Collectivism, Masculinity vs. Femininity, Uncertainty avoidance, Power Distance and Long Term vs. Short Term Orientation. Furthermore, results of Hofestede 
aforementioned studies were used to group cultures of different nations into clusters. For each of these clusters work-related and managerial practices were identified.

There is common fact about culture that it plays as a mechanism to guide individuals' behavior by controlling their values, thoughts and beliefs (Pizam, 1993). According to Griffith (2002), many psychological and behavioral theories (e.g. social cognition models) assert that people perceptions of social environment must be considered in any trial to understand their behavior. The current study does so by exposing the effect of culture on tourists' perceptions and expectations of PPRS. It is established that customers from different cultures tend to be involved in different comparative behaviors and have different expectations of services (Schutte \& Ciarlante, 1998; Patterson \& Smith, 2001; Dunn, 2015).

In addition, the influence of culture on individuals' behavior was confirmed by many studies which investigate different types of behaviours including management and leadership (e.g. Winch, Millar \& Clifton, 1997; Testa, 2004; Moussetis, 2005; Lee, Scandura, \& Sharif, 2014), service encounter (e.g. Winsted, 1997; Donthu \& Yoo, 1998; Furrer et al., 2000; Sizoo, Plank, Iskat \& Serrie, 2005; Zopiatis, Constanti, \& Theocharous, 2014), food handlers' attitude and knowledge (e.g. Toh \& Birchenough, 2000; Harris, Murphy, DiPietro, \& Rivera, 2015), consumer behavior and perceptions (e.g. Pullman, Verman \& Goodale, 2001; Mattila \& Patterson, 2004; Torres, Fu \& Lehto, 2014; Dunn, 2015) and tourist behaviour and satisfaction (e.g. Pizam \& Sussmann, 1995; Becker et al., 1999; Barutcu, Dogan, \& Unguren, 2011; Moital, Dias, \& Machado, 2013). The present research took place in Jordan within the Arabic/Middle Eastern context where job-related practices of food service employees and their impact on customers' satisfaction are expected to be different from those in the West. Also, the current study involves tourists from six cultural groups from different nationalities which are more diversified if compared to previous studies.

\section{Methods}

The influence of national culture on perceived performance of restaurants in Petra city is examined empirically; this approach is justified because there are sufficient numbers of tourists from different nationalities visiting Jordan as a whole and Petra in particular. In 2014, 443,536 tourists visited Jordan, most of them (93.6\%) were non-Jordanians and came from different cultural groups including European countries (58.4\%), Asian and pacific countries (23\%), American countries (11.5\%) other Arabic countries (6.5\%) and African countries (0.5\%) (Jordanian Ministry of Tourism \& Antiquities [JMTA], 2015).

The quantitative data were collected by self-administrated questionnaire developed by Becker et al. (1999). The adopted questionnaire is believed to be a suitable data collection tool, because it was developed in a robust and long process that considered the cultural aspect as well as a set of well-defined restaurant service quality measures. The preliminary stages in the development of the instrument by Becker et al. (1999) were conducted using four focus groups considering multiple cultural backgrounds of participants. Participants in each of the four focus groups were asked to identify specific server behaviors that they associate with quality service in restaurants. Then, the questionnaire was pilot tested in two rounds. First, it was pilot tested on a convenience sample in china. While in the second round, another pilot test was conducted in the United States. After that, two additional focus group discussions were conducted and new scale items were added and several items based on those identified during the pilot studies. Finally, the questionnaire was subject to an exploratory factor analysis to purify its dimensions and to ensure their validity.

The current study's questionnaire comprised two main parts. The first part includes 25 items that measure how tourists perceive restaurant's performance in terms of certain quality elements (servers' accommodation, sanitation, product knowledge, entertainment, professionalism, and cordiality), using a five point scale where $1=$ 'Strongly disagree', 2 = 'Disagree' 3 = 'Neither agree nor disagree' 4 = 'agree' and $5=$ 'Strongly disagree'. The items cover the main elements representing the quality of restaurants' services developed by previously mentioned focus groups. The second part of the questionnaire was developed to collect information about the demographic characteristics of respondents (gender, age \& nationality). Among these variables, the nationality is used in testing study's hypotheses that examine the variability of PPRS among tourists who belong to different cultural groups. Furthermore, information extracted by this part enables the development of a description of the research sample.

The questionnaire was pilot tested; there was no need for adjustments to be made to the structure or terminology. Subsequently, it was completed by 155 tourists from different nationalities who had a meal experience in one of the Petra restaurants, using convenience sampling, which is recommended when the research populations cannot be easily listed. Using the Statistical Package for Social Science (SPSS), some statistical analyses were carried out to achieve the present research objectives. These include internal consistency test (Crombach's alpha) which 
confirmed that study's instrument reliability was good (Cronbach's alpha > 0.7) (Cavana, Delahye, \& Sekran, 2000). Analysis of frequencies delineated the sample profile then One Way ANOVA was used to test the hypotheses; which was followed by descriptive statistics for a better understanding of tourists' perception of restaurants service quality.

\subsection{Study's Hypotheses}

To examine the impact of national culture on tourists' perception of restaurant employees' performance, six hypotheses were developed. These research hypotheses interrelate the constructs of restaurant employees' perceived performance (dependant variables) with the tourist nationality as an indicator of their national culture (independent variable). The following are the study's hypotheses:

Hypothesis 1:

H0: there is no significant difference in the perception of Accommodation traits of restaurant employees' performance between tourists from different national culture groups.

H1: there is a significant difference in the perception of Accommodation traits of restaurant employees' performance between tourists from different national culture groups.

\section{Hypothesis 2:}

H0: there is no significant difference in the perception of Sanitation traits of restaurant employees' performance between tourists from different national culture groups.

H1: there is a significant difference in the perception of Sanitation traits of restaurant employees' performance between tourists from different national culture groups.

Hypothesis 3:

H0: there is no significant difference in the perception of product knowledge traits of restaurant employees' performance between tourists from different national culture groups.

H1: there is a significant difference in the perception of product knowledge traits of restaurant employees' performance between tourists from different national culture groups.

Hypothesis 4:

H0: there is no significant difference in the perception of entertainment traits of restaurant employees' performance between tourists from different national culture groups.

H1: there is a significant difference in the perception of entertainment traits of restaurant employees' performance between tourists from different national culture groups.

Hypothesis 5:

H0: there is no significant difference in the perception of professionalism traits of restaurant employees' performance between tourists from different national culture groups.

H1: there is a significant difference in the perception of professionalism traits of restaurant employees' performance between tourists from different national culture groups.

Hypothesis 6:

H0: there is no significant difference in the perception of cordiality traits of restaurant employees' performance between tourists from different national culture groups.

H1: there is a significant difference in the perception of cordiality traits of restaurant employees' performance between tourists from different national culture groups.

\section{Results}

\subsection{Sample Profile}

This section presents the descriptive analysis of the participants' demographic characteristics including gender, nationality, age and times of visit to Petra. The frequency and percentage distributions of these characteristics are provided in Table 1 and discussed below. 
Table 1. Characteristics of tourists participated in this study

\begin{tabular}{cccc}
\hline Characteristics & Group & Frequency & Percent \\
\hline \multirow{3}{*}{ Gender } & Male & 68 & $43.9 \%$ \\
& Female & 87 & $56.1 \%$ \\
& Total & 155 & $100 \%$ \\
& Less than 25 years & 9 & $5.8 \%$ \\
Age & $25-35$ years & 34 & $21.9 \%$ \\
& $36-45$ years & 23 & $14.8 \%$ \\
& $46-55$ years & 27 & $17.4 \%$ \\
& Over 55 years & 62 & $40 \%$ \\
& Total & 155 & $100 \%$ \\
& Anglo & 37 & $23.9 \%$ \\
Cultures & North European & 32 & $20.6 \%$ \\
& Asian & 54 & $34.8 \%$ \\
& South American & 10 & $6.5 \%$ \\
& East Europe & 10 & $6.5 \%$ \\
& South European & 12 & $7.7 \%$ \\
& Total & 155 & $100 \%$ \\
& First time & 139 & $89.7 \%$ \\
Visit times & I came before & 16 & $10.3 \%$ \\
& Total & 155 & $100 \%$ \\
\hline
\end{tabular}

The sample is divided into two fairly equal subgroups according to the gender of participants: Male (43.9\%) and female $(56.1 \%)$. Amazingly, only $10.3 \%$ of the respondents came to Petra before while others $(89.7 \%)$ it was their first time to visit Petra. The sample was biased towards the elder age group with $72.3 \%$ of the respondents being aged over 36 years, while the remaining $27.7 \%$ of the tourists were less than 35 years of age, indicating a tendency for elder tourists to visit Petra more than young ones, close to the nationality distribution by region of visitors to Jordan, European countries (58.4\%), Asian and pacific countries (23\%), American countries (11.5\%) (JMTA, 2015); A large group of participants 54 (34.8\%) were Asians with 37 (23.9\%) belonging to the Anglo-Saxons culture group, $32(20.6 \%)$ from northern Europe countries, 12 (7.7\%) from southern Europe countries, $10(6.5 \%)$ from eastern European countries and another $10(6.5 \%)$ from South America. In general, the demographic characteristics of the sample were consistent with those found in a previous research by Alhelalat (2010) and those collected by Petra Archeological Park (PAP) and were accessed by personal communication lately. The closeness of the current study's sample characteristics to those collected before by Jordanian tourism authorities and other authors confirmed the degree to which the study's sample is representative.

\subsection{Hypotheses Testing}

As aforementioned, a series of hypotheses were developed to investigate the influence of national culture on tourists' perception of restaurant service performance. Each of these hypotheses was developed to examine the difference in perceptions for each of the restaurant perceived performance constructs between more than two cultural groups of tourists. To test these hypotheses, one-way ANOVA analysis of variance was used. The results of ANOVA analysis of factors composing tourists' perception of restaurant service performance are provided in Table 2.

Table 2. One-way ANOVA results of study's dimensions depending on the culture variable

\begin{tabular}{llllllll}
\hline Variable & Group & Mean & SD & F & df & Sing. & Eta square \\
\hline Accommodation & & & & & & & \\
Cultures & Anglo & 4.08 & 0.59 & 0.770 & 5 & 0.57 & - \\
& North European & 4.20 & 0.56 & & & & \\
& Asian & 4.10 & 0.61 & & & & \\
& South American & 3.73 & 1.38 & & & & \\
& East European & 4.28 & 0.64 & & & & \\
& South European & 4.03 & 0.93 & & & & \\
Sanitation & & & & & & & \\
Cultures & Anglo & 4.67 & 0.57 & 2.86 & 5 & 0.017 \\
\hline
\end{tabular}




\begin{tabular}{|c|c|c|c|c|c|c|c|}
\hline & North European & 4.45 & 0.61 & & & & \\
\hline & Asian & 4.40 & 0.51 & & & & \\
\hline & South American & 4.05 & 0.79 & & & & \\
\hline & East European & 4.00 & 0.88 & & & & \\
\hline & South European & 4.25 & 081 & & & & \\
\hline \multicolumn{8}{|c|}{ Knowledge } \\
\hline \multirow[t]{6}{*}{ Cultures } & Anglo & 3.60 & 1.08 & 2.708 & 5 & 0.023 & 0.092 \\
\hline & North European & 4.11 & 0.69 & & & & \\
\hline & Asian & 3.47 & 0.79 & & & & \\
\hline & South American & 3.72 & 1.65 & & & & \\
\hline & East European & 4.22 & 1.00 & & & & \\
\hline & South European & 3.20 & 1.15 & & & & \\
\hline \multicolumn{8}{|c|}{ Entertainment } \\
\hline \multirow[t]{6}{*}{ Cultures } & Anglo & 3.42 & 0.82 & 4.559 & 5 & 0.001 & 0.14 \\
\hline & North European & 4.25 & 0.69 & & & & \\
\hline & Asian & 3.65 & 0.83 & & & & \\
\hline & South American & 3.84 & 0.34 & & & & \\
\hline & East European & 4.24 & 0.93 & & & & \\
\hline & South European & 3.30 & 082 & & & & \\
\hline \multicolumn{8}{|c|}{ Professionalism } \\
\hline \multirow[t]{6}{*}{ Cultures } & Anglo & 4.15 & 0.74 & 1.606 & 5 & 0.163 & - \\
\hline & North European & 4.39 & 052 & & & & \\
\hline & Asian & 4.17 & 0.66 & & & & \\
\hline & South American & 4.02 & 0.98 & & & & \\
\hline & East European & 4.62 & 0.39 & & & & \\
\hline & South European & 3.95 & 0.97 & & & & \\
\hline \multicolumn{8}{|c|}{ Cordiality } \\
\hline \multirow[t]{6}{*}{ Cultures } & Anglo & 4.49 & 0.50 & 1.528 & 5 & 1.62 & - \\
\hline & North European & 4.45 & 050 & & & & \\
\hline & Asian & 4.25 & 0.55 & & & & \\
\hline & South American & 3.89 & 1.10 & & & & \\
\hline & East European & 4.32 & 0.55 & & & & \\
\hline & South European & 4.48 & 1.08 & & & & \\
\hline
\end{tabular}

Result shown in the table above divide RSPP factors into two groups based on the variation of their scores dependency on national culture variable. Within the first group a statistically significant difference was found in tourists' perception of sanitation: $F(5,142)=2.866$, product knowledge: $F(5,133)=2.719$, and entertainment: $F$ $(5,139)=4.559$, for all national groups. These results support the alternative hypothesis and reject the null one of hypotheses 2, 3 and 4. Furthermore, Table 2 shows the Eta squared values that identify the effect size of previously mentioned significant differences. These eta squared values indicate that the actual difference in mean scores between different national culture groups for entertainment (14\%) was large and moderate for both product knowledge (9.2\%) and sanitation (9.1\%), this according to the guide lines of Cohen (1988).

In the other group there was no statistically significant difference found in tourists' perception of accommodation: $\mathrm{F}(5,132)=0.77$, professionalism: $\mathrm{F}(5,137)=1.606$, and cordiality: $\mathrm{F}(5,130)=1.628$, for all national groups. These results support the null hypothesis and reject the alternative one of hypotheses 1, 5 and 6.

However, in spite that ANOVA test (Table 2) shows some factors had no significant variance in their aggregate scores (factors tested in hypotheses $1,5 \& 6$ ); there is still a chance that these factors are perceived in different way across cultures. In other words, cultures may give the equal importance relatively to certain factors but do not necessarily perceive them in a similar way. Accordingly, for deeper investigation, a break down analysis was carried out on means of items composing the study's dimensions. The means of each of these items were compared separately across different cultural groups. Results of this comparison are shown in Table 3 below. 
Table 3. Descriptive statistics of statements for all factors of RSPP

\begin{tabular}{|c|c|c|c|c|c|c|c|c|c|c|c|c|c|}
\hline \multirow[t]{2}{*}{ No. } & \multirow[t]{2}{*}{ Factors' Items } & \multicolumn{2}{|c|}{ Anglo-Saxons } & \multicolumn{2}{|c|}{$\begin{array}{c}\text { North } \\
\text { Europeans }\end{array}$} & \multicolumn{2}{|c|}{ Asians } & \multicolumn{2}{|c|}{$\begin{array}{c}\text { South } \\
\text { Americans }\end{array}$} & \multicolumn{2}{|c|}{$\begin{array}{c}\text { East } \\
\text { Europeans }\end{array}$} & \multicolumn{2}{|c|}{$\begin{array}{c}\text { South } \\
\text { Europeans }\end{array}$} \\
\hline & & $\mathrm{M}$ & SD & $\mathrm{M}$ & $\mathrm{SD}$ & $\mathrm{M}$ & SD & M & SD & M & SD & M & SD \\
\hline \multicolumn{14}{|c|}{ Factor 1: Accommodation } \\
\hline 1 & $\begin{array}{l}\text { The server provides for } \\
\text { the customer's special } \\
\text { needs when asked }\end{array}$ & 4.38 & 0.79 & 4.52 & 0.5 & 4.17 & 0.69 & 3.8 & 1.13 & 4.3 & 1.25 & 3.92 & 0.99 \\
\hline 2 & $\begin{array}{l}\text { The server attends to } \\
\text { special customer needs } \\
\text { without being asked }\end{array}$ & 3.77 & 0.87 & 4.1 & 0.83 & 4.07 & 0.74 & 3.8 & 1.47 & 4.4 & 0.84 & 3.92 & 1.16 \\
\hline 3 & $\begin{array}{l}\text { The server } \\
\text { accommodates special } \\
\text { requests of the } \\
\text { customer }\end{array}$ & 3.94 & 0.78 & 4.03 & 0.79 & 4.06 & 0.74 & 3.8 & 1.13 & 4.44 & 0.72 & 4 & 1.12 \\
\hline 4 & $\begin{array}{l}\text { The server is sensitive } \\
\text { to the customer's mood }\end{array}$ & 4.03 & 0.98 & 4.27 & 0.78 & 4.13 & 0.83 & 3.8 & 1.54 & 4.3 & 0.82 & 4.33 & 0.98 \\
\hline 5 & $\begin{array}{l}\text { The server stops by } \\
\text { frequently to check for } \\
\text { additional customer } \\
\text { needs }\end{array}$ & 4.06 & 0.87 & 4.24 & 0.78 & 4.1 & 0.91 & 3.67 & 1.65 & 4.1 & 1.1 & 4 & 1.12 \\
\hline Over & 1 mean & 4.03 & & 4.23 & & 4.1 & & 3.77 & & 4.3 & & 4.03 & \\
\hline \multicolumn{14}{|c|}{ Factor 2: Sanitation } \\
\hline 6 & $\begin{array}{l}\text { The server's hair is } \\
\text { neat and well groomed }\end{array}$ & 4.73 & 0.56 & 4.4 & 0.77 & 4.56 & 0.5 & 4.1 & 0.73 & 3.6 & 1.57 & 4.42 & 0.79 \\
\hline 7 & $\begin{array}{l}\text { The server's hair is } \\
\text { clean and restrained }\end{array}$ & 4.7 & 0.57 & 4.52 & 0.62 & 4.44 & 0.53 & 4.1 & 0.87 & 4.4 & 0.69 & 4.5 & 0.9 \\
\hline 8 & $\begin{array}{l}\text { The server's nails and } \\
\text { hands are well } \\
\text { manicured }\end{array}$ & 4.64 & 0.65 & 4.5 & 0.9 & 4.32 & 0.7 & 4.1 & 0.87 & 4.4 & 0.84 & 4.08 & 0.99 \\
\hline 9 & $\begin{array}{l}\text { The server avoids } \\
\text { touching the surface of } \\
\text { eating utensils }\end{array}$ & 4.62 & 0.68 & 4.39 & 0.76 & 4.28 & 0.62 & 3.9 & 0.99 & 3.6 & 1.57 & 4 & 1.2 \\
\hline Over & 1 mean & 4.67 & & 4.45 & & 4.4 & & 4.05 & & 4 & & 4.25 & \\
\hline \multicolumn{14}{|c|}{ Factor 3: Product knowledge } \\
\hline 10 & $\begin{array}{l}\text { The server explains } \\
\text { menu item ingredients }\end{array}$ & 3.89 & 1.21 & 4.41 & 0.73 & 3.57 & 0.9 & 3.8 & 1.68 & 4.4 & 0.96 & 3.25 & 1.48 \\
\hline 11 & $\begin{array}{l}\text { The server thoroughly } \\
\text { explains menu specials }\end{array}$ & 3.68 & 1.14 & 4.21 & 0.77 & 3.5 & 0.92 & 3.6 & 1.71 & 4.3 & 1.16 & 3.5 & 1.24 \\
\hline 12 & $\begin{array}{l}\text { The server explains } \\
\text { how menu items are } \\
\text { prepared or cooked }\end{array}$ & 3.36 & 1.02 & 4.13 & 1.04 & 3.3 & 0.95 & 3.7 & 1.63 & 4.2 & 1.13 & 2.5 & 1.44 \\
\hline 13 & $\begin{array}{l}\text { The server assists the } \\
\text { customer in deciding } \\
\text { what to order }\end{array}$ & 3.44 & 1.16 & 3.93 & 0.88 & 3.48 & 0.85 & 3.7 & 1.63 & 4 & 1.15 & 3 & 1.26 \\
\hline 14 & $\begin{array}{l}\text { The server clarifies any } \\
\text { uncertainty about food } \\
\text { items listed on the } \\
\text { menu }\end{array}$ & 3.91 & 1.14 & 4.1 & 0.81 & 3.6 & 0.98 & 3.8 & 1.68 & 4.2 & 0.91 & 3.42 & 1.08 \\
\hline Over & 1 mean & 3.65 & & 4.15 & & 3.49 & & 3.72 & & 4.22 & & 3.13 & \\
\hline \multicolumn{14}{|c|}{ Factor 4: Entertainment } \\
\hline 15 & $\begin{array}{l}\text { The server entertains } \\
\text { the customers with } \\
\text { jokes and stories }\end{array}$ & 2.91 & 1.07 & 4.16 & 0.93 & 3.23 & 1.16 & 3.7 & 1.56 & 3.9 & 1.52 & 2.75 & 1.13 \\
\hline 16 & $\begin{array}{l}\text { The server provides } \\
\text { friendly conversation }\end{array}$ & 3.82 & 1.1 & 4.32 & 0.87 & 3.69 & 1.14 & 3.7 & 1.56 & 4.3 & 1.16 & 3.67 & 1.55 \\
\hline
\end{tabular}




\begin{tabular}{|c|c|c|c|c|c|c|c|c|c|c|c|c|c|}
\hline 17 & $\begin{array}{l}\text { The server behaves in a } \\
\text { way that entertains the } \\
\text { customer }\end{array}$ & 3.24 & 1.06 & 4.23 & 0.8 & 3.65 & 1.08 & 3.7 & 1.56 & 4.1 & 1.19 & 3.17 & 1.03 \\
\hline 18 & $\begin{array}{l}\text { When dining alone, } \\
\text { server spends more } \\
\text { time conversing with } \\
\text { customer }\end{array}$ & 3.34 & 1.28 & 4.23 & 0.8 & 3.76 & 1 & 4 & 1.05 & 4.3 & 1.05 & 3.08 & 1.31 \\
\hline 19 & $\begin{array}{l}\text { The server behaves in a } \\
\text { casual manner }\end{array}$ & 4.03 & 1.08 & 4.37 & 0.76 & 3.96 & 0.82 & 4.1 & 1.1 & 4.6 & 0.51 & 3.83 & 0.83 \\
\hline \multirow{2}{*}{\multicolumn{2}{|c|}{$\begin{array}{l}\text { Overall mean } \\
\text { Factor 5: Professionalism }\end{array}$}} & 3.46 & & 4.26 & & 3.65 & & 3.84 & & 4.24 & & 3.3 & \\
\hline & & & & & & & & & & & & & \\
\hline 20 & $\begin{array}{l}\text { The server knows when } \\
\text { the customer does not } \\
\text { want to be bothered }\end{array}$ & 4.29 & 0.98 & 4.33 & 0.75 & 4.15 & 0.83 & 3.9 & 1.1 & 4.6 & 0.51 & 3.67 & 1.49 \\
\hline 21 & $\begin{array}{lr}\text { The server } & \text { does not } \\
\text { interrupt } & \text { customers } \\
\text { conversing } & \text { among } \\
\text { themselves } & \end{array}$ & 3.79 & 1 & 4.27 & 0.64 & 4.15 & 0.78 & 4.1 & 1.1 & 4.6 & 0.69 & 3.75 & 1.13 \\
\hline 22 & $\begin{array}{l}\text { When appropriate, the } \\
\text { server speeds up the } \\
\text { pace of the service }\end{array}$ & 4.06 & 1.02 & 4.39 & 0.68 & 4.06 & 0.82 & 4.1 & 0.73 & 4.5 & 0.7 & 4.08 & 0.99 \\
\hline 23 & $\begin{array}{l}\text { The server allows the } \\
\text { customer opportunity } \\
\text { for privacy }\end{array}$ & 4.64 & 0.63 & 4.65 & 0.55 & 4.41 & 0.71 & 4 & 1.24 & 4.8 & 0.42 & 4.33 & 0.77 \\
\hline \multicolumn{2}{|c|}{ Overall mean } & 4.19 & & 4.41 & & 4.19 & & 4.02 & & 4.62 & & 3.95 & \\
\hline \multicolumn{14}{|c|}{ Factor 6: Cordiality } \\
\hline 24 & $\begin{array}{l}\text { The server smiles when } \\
\text { greeting the customer }\end{array}$ & 4.56 & 0.69 & 4.58 & 0.62 & 4.28 & 0.73 & 4 & 1.24 & 4.6 & 0.69 & 4.33 & 0.88 \\
\hline 25 & $\begin{array}{l}\text { The server makes } \\
\text { direct eye contact with } \\
\text { the customer }\end{array}$ & 4.62 & 0.79 & 4.65 & 0.55 & 4.31 & 0.74 & 4.1 & 1.1 & 4.6 & 0.96 & 4.5 & 0.79 \\
\hline 26 & $\begin{array}{l}\text { The server's clothes are } \\
\text { well maintained }\end{array}$ & 4.08 & 0.59 & 4.21 & 0.55 & 4.1 & 0.61 & 3.73 & 1.38 & 4.29 & 0.64 & 4.85 & 3.14 \\
\hline 27 & $\begin{array}{l}\text { The server's manner } \\
\text { makes the customer } \\
\text { feel comfortable }\end{array}$ & 4.67 & 0.57 & 4.47 & 0.62 & 4.41 & 0.51 & 4.05 & 0.79 & 4 & 0.89 & 4.25 & 0.81 \\
\hline \multicolumn{2}{|c|}{ Overall mean } & 4.48 & & 4.47 & & 4.27 & & 3.97 & & 4.37 & & 4.48 & \\
\hline
\end{tabular}

The aforementioned comparison helped in understanding whether national culture affects indirectly some factors by influencing some of their aspects; though there was not a clear impact on them in the aggregate level. The table above depicted clearly how various cultures perceive different factors' items of PPRS. Table 3 results revealed that although tourists from different cultures valued some PPRS dimensions equally, meaningful differences were found in some items composing these dimensions:

-Accommodation: Some of this factor's elements were evaluated differently by cultural groups. For example, Latin cultural groups (South Europeans \& South Americans) gave less importance to servers responsiveness to guests' special needs (item 1) and to servers' frequent check of additional needs (item 5) compared to other cultural groups.

-Professionalism: This factor was also evaluated equally (considering the aggregate level) by different cultural groups. However, some of its components were valued unequally by some cultural groups. For example, statements that measure how server avoid bothering customers and respect their privacy (item 20 \& item 23) were valued very important by Eastern Europeans more than any other cultural groups.

-Cordiality: Like the previous two factors, some cultural groups were differentiated in their evaluation for some of the cordiality factor's items. For example, while the Eastern Europeans valued strongly servers' smile (item 24) the South Europeans achieved the strongest degree in valuation of servers' clothes well maintaining (item 26). 


\section{Discussion}

Results reported by the current study support its general hypothesis that cultural orientation of customers influences their expectations of service. However, the effect of culture on tourists' expectation was direct on some of the service quality factors and indirect on others.

The examination of the previous six hypotheses revealed that national culture has an influence on the PPRS factors canvassed in the current study. However, this influence varies in manner between these factors. Half of these factors (entertainment, product knowledge and sanitation) were affected directly. A significant variance was found in the aggregate scores of these factors due to the effect of national culture. The size of that effect was different for each of these factors. It was moderate for sanitation (9.1\%) and product knowledge $(9.2 \%)$ and large for entertainment (14\%).

Entertainment as aforementioned showed the largest variance of tourists' perception as a function of their national culture. However, North and East European groups ranked this dimension higher than other groups. This can be attributed to the age factor. Most of the two groups (54.5\% of the North Europeans \& 80\% of East Europeans) are younger than 35 years old.

Product knowledge is the second dimension in terms of cultural size of impact on it. Again, the North Europeans and Eastern European tourists achieved the highest rank for the product knowledge (food \& beverage) provided by restaurants' servers at Petra-Jordan. The main explanation of this phenomenon is that most of the societies within these two cultural groups have high uncertainty avoidance. The uncertainty avoidance dimension revealed to which extent members of a certain culture feel that they are threatened by unknown or ambiguous situation (Hofstede \& Hofstede, 2005). Accordingly, people of such cultures are expected to look desperately for information about new places and products. This explanation is justified since most of the sample subjects from both culture (78.1\% of the North Europeans \& $99.7 \%$ of the East Europeans) are visiting Jordan for the first time which represent a new situation for them.

Another factor that showed significant differences between tourists as a function of national culture is sanitation. The ANOVA analysis (Table 2) shows that variation in this dimension is medium (effect size 9.1\%) and that all groups showed a relatively similar concern of food safety. This could be due to the growing awareness of food safety issues around the world (Burros, 1997; Käferstein, Motarjemi \& Bettcher, 1997; Käferstein \& Abdusalam, 1999). However, the South Americans showed the least valuation of many sanitation dimension's items (Table $3)$.

The other half of factors was affected indirectly. In spite, there was no significant variance found in these variables' scores, some variation was found in the mean scores of elements composing them. Accommodation is one of these factors where tourists valued some if its items unequally. As mentioned before, Latin cultural groups (South Americans \& South Europeans) valued most the Accommodation's items (especially item $1 \& 5$ ) less than other cultural groups. Latin cultures are considered to be collectivist ones. This implies a relationship between collectivism and Accommodation factor. In Collectivism, people tend to be involved cohesively in groups where everyone look after each other and not to be individualized from others (Hofstede \& Hofstede, 2005). The tenor of Collectivism contradicts with content of Accommodation's items; which emphasize in individualizing guests in provided services. This finding consists with what was found in Becker et al. (1999). According to Becker et al. (1999), it was found that U.S.A participants (who are described as highly individualists) valued greatly the items of Accommodation factor in comparison to Hong Kong participants (who are considered to be collectivists).

Professionalism is another variable within the second half of factors mentioned above. Most of items composing professionalism factor were strongly valued by East European tourists (see Table 3). An explanation of this strong valuation is that East Europe societies generally are considered to have high rates in power distance dimension. A closer look to professionalism elements can reveals that the crux of professionalism is very close to essence of power distance dimension. Power distance is defined as "the extent to which the less powerful members of institutions and organizations within a country expect and accept that power is distributed unequally" (Hofstede \& Hofstede, 2005, p. 46). In societies where power distance is high, a hierarchically status rules are practiced in real social life and expected. Accordingly, members of such societies believe that others should treat them with respect to their status. For example, a server must respect her/his guest and shall treat her/him in a unobtrusive style.

Similar to the accommodation and professionalism, cordiality was also valued equally as a whole by different tourists. However, there was inequality in the scores of some cordiality elements between some cultural groups. Nevertheless, this inequality was not taking place in a consistent rhythm, which confuses the reading of culture 
impact on this dimension. Thus, a more research for the relationship of national culture and cordiality is suggested.

\section{Conclusion, Recommendations and Limitations}

Based on the discussion above it can be concluded that national culture plays a crucial role in forming tourists' evaluation of PPRS. In other words, national culture affects tourists' valuation of offered services. This effect may happen by building tourists' expectation of service in advance based on their cultural values. For example, if a tourist belongs to an individualistic culture s/he will mostly expect to be served in an individualized manner and not in a standard one. However, the impact of culture on tourists' perception of food services may not be prominent. Tourists from different cultures may agree on the importance of a certain factor of perceived service; but they do not value all of its elements equally.

Based on present study's findings, which highlighted the influence of culture on tourists' perception, recommendations were suggested. These recommendations are expected to help tourism industry stakeholders in enhancing tourists' satisfaction; which in turn conduce in the success of different hospitality organizations. Among these recommendations, the Jordanian Ministry of Tourism and Antiquities (JMTA) is advocated to enhance the awareness and acceptance of cultural differences of tourists among those working in the hospitality industry. Such enhancement can be achieved by supporting training on cultures of other nations. Furthermore, Jordanian tourism authorities (such as JMTA \& the Jordanian Tourism Board (JTB)) are advised to consider cultural issues when promoting Jordan to international tourism. They can emphasize on tourists interests according to their national cultural traits. For example, in some cultures people might be concerned more about materialistic issues such as accommodation while other cultures might be more emotive focusing on issues such as cordiality.

Another recommendation was proposed for various managers working in any hospitality establishment (especially foodservice businesses) to consider their guests cultures as a determinant of satisfaction. Managers can even convert the challenge of cultural differences into an opportunity by offering innovative products that accommodate their cultural needs. Also, hospitality managers are advised to form feedback systems which are sensitive to cultural needs of their guests.

The current research encountered some limitations including time constraints because researchers were not fully devoted to the work of this research due to their lecturing obligations (more than $12 \mathrm{~h} /$ week), financial limitations (this research was financed by researchers' self-funds) and the unavailability of population framework which coerced to the use of convenient sampling method. Accordingly, it is suggested to repeat this research in within better conditions and in a context where population frame work is available which enables the use of random sampling techniques. In addition, the current study was not able to offer an explanation of some phenomena due to the inconsistent manner of tourists' valuation for some of PPRS factors (such as cordiality). Thus, a better explanation is expected to be achieved if a future qualitative research is carried out to study these factors separately.

\section{References}

Akbaba, A. (2006). Measuring service quality in the hotel industry: A study in a business hotel in Turkey. $\begin{array}{lllll}\text { International Journal of } & \text { Hospitality }\end{array}$ http://dx.doi.org/10.1016/j.ijhm.2005.08.006

Alhelalat, J. A. (2010). Electronic Relationship Value Management in the Hotel Industry: An Empirical Examination of Classified Hotels in Petra, Jordan (Doctoral Thesis). Manchester Metropolitan University, Manchester.

Baker, T., Meyer, T., \& Chebat, J. (2013). Cultural impact on felt and expressed emotions and third party complaint relationships. Journal of Business Research, 77(7), 816-822. http://dx.doi.org/10.1016/j.jbusres.2011.06.006

Barutcu, S., Dogan, H., \& Unguren, E. (2011). Tourists' perception and satisfaction of shopping in Alanya region: A comparative analysis of different nationalities. Procedia-Social and Behavioral Sciences, 24, 1049-1059. http://dx.doi.org/10.1016/j.sbspro.2011.09.101

Becker, C., Murrmann. S. K., \& Cheung, G. W. (1999). A pancultural study of restaurant service expectations in United States and Hong Kong. Journal of Hospitality and Tourism Research, 23(5), 235-255. http://dx.doi.org/10.1177/109634809902300301

Bolton, R. N., \& Drew, J. H. (1991). A Multistage Model of Customers' Assessments of Service Quality and 
Value. Journal of Consumer Research, 17(4), 375-385.

Brown, S. P., \& Lam, S. K. (2008). A Meta-Analysis of Relationships Linking Employee Satisfaction to Customer Responses. Journal of Retailing, 84(3), 243-255. http://dx.doi.org/10.1016/j.jretai.2008.06.001

Burros, M. (1997). Clinton to Battle Food borne Illness. Retrieved from http://query.nytimes.com/gst/fullpage.html?sec=health\&res=9806E1DF123AF936A15752C0A961958260

Carrillat, F. A., Jaramillo, F., \& Mulki, J. P. (2007). The validity of the SERVQUAL and SERVPERF scales: A meta-analytic view of 17 years of research across five continents. International Journal of Service Industry Management, 18(5), 472-490. http://dx.doi.org/10.1108/09564230710826250

Cavana, R., Delahye, B., \& Sekaran, U. (2000). Applied Business research: Qualitative and Quantitative Methods. NY: John Wiley \& Sons Australia, Ltd.

Chang, L. (2003). An examination of Cross-cultural negotiation: Using Hofstede framework. Journal of American Academy of Business, 2(2), 567-570.

Donthu, N., \& Yoo, B. (1998). Cultural influences of service quality expectation. Journal of Service Research, 2(1), 178-186. http://dx.doi.org/10.1177/109467059800100207

Dunn, K. (2015). Globalization and consumer: What marketer needs to know. The Neumann Business Review, 16-30. Retrieved from https://www.neumann.edu/academics/divisions/business/journal/index.html

Furrer, O., Liu, B. S., \& Sudharshan, D. (2000). The relationships between cultures and service quality perceptions: Basis for cross-cultural market segmentation and resource allocation. Journal of Service Research, 4(2), 355-371. http://dx.doi.org/10.1177/109467050024004

Fen, Y. S., \& Lian, K. (2005). Service quality and customer satisfaction: Antecedents of customers' re-patronage intentions. Sun. Acad. J., 4(1), 60-73.

Gagić, S., Tešanović, D., \& Jovičić, A. (2013). The Vital Components of Restaurant Quality that Affect Guest Satisfaction. TURIZAM, 17(4), 166-176.

Griffith, C. (2002). Good practices for food handlers and consumers. In C. W. Blackburn, \& P. J. McClure (Eds.), Food borne pathogens: Hazards, risk analysis and control (pp. 257-274). Cambridge: Woodhead Publishing Limited.

Grönroos, C. (1994). From Scientific Management to Service Management: A Management Perspective for the Age of Service Competition. International Journal of Service Industry Management, 5(1), 5-20. http://dx.doi.org/10.1108/09564239410051885

Ha, J., \& Jang, S. (2010). Perceived values, satisfaction, and behavioral intentions: The role of familiarity in Korean restaurants. International Journal of Hospitality Management, 29(1), 2-13. http://dx.doi.org/10.1016/j.ijhm.2009.03.009

Harris, K. J., Murphy, K. S., DiPietro, R. B., \& Rivera, J. L. (2015). Food safety inspections result: A comparison of ethnic-operated restaurants to non-ethnic-operated restaurants. International Journal of Hospitality Management, 46, 190-199. http://dx.doi.org/10.1016/j.ijhm.2015.02.004

Harvey, F. (1997). National cultural differences in theory and practice: Evaluating Hofstede's national cultural framework. Information Technology \& People, 2(10), 132-146.

Hofstede, G. (1980). Culture's Consequences: International Differences in work-related Values. London: Sage.

Hofstede, G. (1991). Cultures and Organisations: Software of the Mind. London: McGrew-Hill International Limited.

Hofstede, G. (2001). Cultures Consequences: comparing Values, Behaviours, Institutions, and Organisations across Nations (2nd ed.). London: Sage Publications.

Hofstede, G., \& Hofstede, G. J. (2005). Cultures and Organisations: Software of the Mind. New York: McGraw-Hill.

Humphreys, M. (1996). Culture difference and its effect on the management of technical education. Leadership and Organisation Development Journal, 2(17), 34-41. http://dx.doi.org/10.1108/01437739610111213

Johnston, R. (1995). The determinants of service quality: Satisfiers and dissatisfiers. International Journal of Service Industry Management, 6(5), 53-71. http://dx.doi.org/10.1108/09564239510101536

Jordanian Ministry of Tourism and Antiquities. (2014). Tourism Statistical Newsletter 2014 [Online]. Retrieved 
from http://mota.gov.jo/Contents/Tourism_Statistical_Newsletter_2014Ar.aspx

Käferstein, F., \& Abdussalam, M. (1999). Food safety in the 21st century. Bulletin of the World Health Organization, 77(4), 347-351.

Käferstein, F. K., Motarjemi, Y., \& Bettcher, D. W. (1997). Food borne disease control: A transnational challenge. Emerging Infectious Disease, 3(4), 503-510.

Kang, G., \& James, J. (2004). Service quality dimensions: An examination of Grönroos's service quality model. Managing Service Quality: An International Journal, 14(4), 266-277. http://dx.doi.org/10.1108/09604520410546806

Kanousi, A. (2005). An empirical investigation of the role of culture on service recovery expectations. Managing Service Quality, 1(15), 57-69. http://dx.doi.org/10.1108/09604520510575263

Kariru, A. N., \& Aloo, C. (2014) Customers perceptions and expectations of service quality in hotels in western tourism circuit, Kenya. Journal of Research in Hospitality, Tourism and Culture, 2(1), 1-12. http://dx.doi.org/10.14303/jrhtc.2013.100

Kotler, P., \& Keller, K. L. (2012). Marketing Management (14th ed.). NJ: Prentice Hall.

Kumar, V., Batista, L., \& Maull, R. (2011). The Impact of Operations Performance on Customer Loyalty. Service Science, 3(2), 158-171. http://dx.doi.org/10.1287/serv.3.2.158

Kuo, C., \& Hsiao, S. (2013). A Perspectives Comparison: The Importance and Features of Service Attitude between International Hotel Employees and Guests. Journal of International Management Studies, 8(2), $35-44$.

Kusluvan, S. (2003). Employee attitudes and behaviors and their roles for tourism and hospitality businesses. In S. Kusluvan (Ed.), Managing employee attitudes and behaviors in the tourism and hospitality (pp. 25-50). New York: Nova Science Publishers.

Lee, K., Scandura, T. A., \& Sharif, M. M. (2014). Cultures have consequences: A configural approach to leadership across two cultures. The Leadership Quarterly, 25(4), 692-710. http://dx.doi.org/10.1016/j.leaqua.2014.03.003

Manhas, P. S., \& Ramjit, J. (2011). Customer Perception of Service Quality in Hospitality Industry: Importance Performance Analysis. Tourism Issues, 14, 97-113.

Mattila, A. S., \& Patterson, P. G. (2004). The impact of culture on consumers' perceptions of service recovery efforts. Journal of Retailing, 80(3), 196-206.

Mazanec, J. A., Crotts, J. C., Gursoy, D., \& Lu, L. (2015). Homogeneity versus heterogeneity of cultural values: An item-response theoretical approach applying Hofestede's cultural dimensions in a single nation. Tourism Management, 48, 299-304. http://dx.doi.org/10.1016/j.tourman.2014.11.011

McCain, S., Jang, S., \& Hu, C. (2005). Service quality gap analysis toward customer loyalty: Practical guidelines for casino hotels. International Journal of Hospitality Management, 24(3), 465-472. http://dx.doi.org/10.1016/j.ijhm.2004.09.005

Maheswaran, D., \& Shavitt, S. (2000). Issues and new directions in global consumer psychology. Journal of Consumer Psychology, 9(2), 59-66.

Mei, A. M. O., Dean, A. M., \& White, C. J. (1999). Analysing service quality in the hospitality industry. Managing Service Quality: An International Journal, 9(2), 136-143. http://dx.doi.org/10.1108/09604529910257920

Mitra, D., \& Peter, G. (2006). How Does Objective Quality Affect Perceived Quality? Short-Term Effects, Long-Term Effects, and Asymmetries. Marketing Science, 25(3), 230-247. http://dx.doi.org/10.1287/mksc.1050.0175

Moital, M., Dias, N. R., \& Machado, D. F. C. (2013). A cross cultural study of golf tourists's satisfaction. Journal of Destination Marketing and Management, 2(1), 39-45. http://dx.doi.org/10.1016/j.jdmm.2013.02.003

Mooij, M. (2010). Consumer and Behavior: Consequences for Global Marketing and Advertising. London: SAGE Publishing, Inc.

Moussetis, R. C., Abu Rahma, A., \& Nakos, G. (2005). Strategic behaviour and national culture: The case of the banking industry in Jordan. Competitiveness Review, 2(15), 101-115.

Mwaura, G., Sutton, J., \& Roberts, D. (1998). Corporate and national culture-an irreconcilable dilemma for the 
hospitality managers? International Journal of Contemporary Hospitality Management, 6(10), 212-220. http://dx.doi.org/10.1108/09596119810232211

Parasuraman, A., Zeithaml, V. A., \& Berry, L. L. (1988). SERVQUAL: A multiple-item scale for measuring customer perceptions of service quality. Journal of Retailing, 6(41), 12-40.

Park, H. (2011). Man-made disasters: A cross-national analysis. International Business Review, 20(4), 466-476. http://dx.doi.org/10.1016/j.ibusrev.2010.080004

Patterson, P. G., \& Smith, T. (2001). Modelling relationship strength across service types in a South-East-Asian context. International Journal of Service industry Management, 12(2), 90-113. http://dx.doi.org/10.1108/09564230110387470

Phiri, M. A., \& Mcwabe, T. (2013). Customer Expectation and Perception of Service Quality: The Case of Pick N Pay Supermarket in Pietermaritzburg Area, South Africa. International Journal of Research in Social Science, 3(1), 97-104.

Pizam, A. (1993). Managing cross-cultural hospitality enterprises. In P. Jones, \& A. Pizam (Eds.), The International Hospitality Industry: Organisational and Operational Issues (pp. 205-226). London: Addison Wesley Longman Limited.

Pizam, A., \& Sussmann, S. (1995). Does nationality affect tourist behaviour? Annals of Tourism Research, 22(4), 901-917. http://dx.doi.org/10.1016/0160-7383(95)00023-5

Pullman, M. E., Verman, R., \& Goodale, J. C. (2001). Service design and operations strategy formulation in multicultural markets. Journal of Operations Management, 2(19), 239-254. http://dx.doi.org/10.1016/S0272-6963(00)00059-0

Rao, P. S., \& Sahu, P. C. (2013). Impact of Service Quality on Customer Satisfaction in Hotel Industry. IOSR Journal of Humanities and Social Science. 18(5), 39-44.

Robbins, S. S., \& Stylianou, A. C. (2001). A study of cultural differences in global corporate Websites. Journal of Computer Information Systems, 42(2), 3-9.

Schermerhorn, J. R., \& Bond, M. H. (1997). Cross-cultural leadership dynamics in collectivism and high power distance settings. Leadership and Organisation Development Journal, 4(18), 187-193.

Schneider, S. C., \& Barsoux, J. L. (2003). Managing across Cultures. Harlow: Pearson Education Limited.

Schutte, H., \& Ciarlante, D. (1998). Consumer Behaviour in Asia. Hampshire: Macmillan Business.

Sizoo, S., Plank, R., Iskat, W., \& Serrie, H. (2005). The effect of intercultural sensitivity on employee performance in cross-cultural service encounter. Journal of Service Marketing, 19(4), 245-255. http://dx.doi.org/10.1108/08876040510605271

Søndergaard, M. (1994). Hofstede's consequences: A study of reviews, citations and replications. Organisation Studies, 3(15), 447-456.

Tawakoli, M., \& Tawakoli, A. (2010). A cross cultural study of advice and social pressure. Procedia Social and Behavioral Science, 5, 1533-1539. http://dx.doi.org/10.1016/j.sbspro.2010.07.321

Teas, R. K. (1993). Expectations, performance evaluation and consumers perception of quality. Journal of Marketing, 57, 18-34. http://dx.doi.org/10.2307/1252216

Testa, M. R. (2004). Cultural similarity and service leadership: A look at the cruise industry. Managing Service Quality, 5(14), 402-413. http://dx.doi.org/10.1108/09604520410558001

Toh, P. S., \& Birchenough, A. (2000). Food safety knowledge and attitudes: culture and environment impact on hawkers in Malaysia. Food Control, 11, 447-452.

Torres, E. N., Fu, X., \& Lehto, X. (2014). Examining key divers of customer delight in a hotel experience: A cross cultural perspective. International Journal of Hospitality Management, 36, 255-262. http://dx.doi.org/10.1016/j.ijhm.2013.09.007

Winch, G., Millar, C., \& Clifton, N. (1997). Culture and organization the case of Transmanche-Link. British Journal of Management, 3(8), 237-250.

Winsted, K. F. (1997). The service experience in two cultures: A behavior perspective. Journal of Retailing, 73(3), 337-360. http://dx.doi.org/10.1016/S0022-4359(97)90022-1

Wu, C. H., \& Liang R. D. (2009). Effect of experiential value on customer satisfaction with service encounters in 
luxury-hotel restaurants. International Journal of Hospitality Management, 28(4), 568-594. http://dx.doi.org/10.1016/j.ijhm.2009.03.008

Yoo, S. A. (2012). Customer Perceptions of Restaurant Cleanliness: A Cross Cultural Study (Masters Dissertation). Virginia Polytechnic Institute, Virginia.

Zeithaml, V., Bitner, M. J., \& Gremler, D. D. (2009). Services Marketing: Integrating Customer Focus across the Firm (5th ed.). New York: McGraw-Hill.

Zhang, Y. (2008). Problems Existing in China's Hotel Service and Study on the Strategy from the Aspect of Customer Value. Journal of Politics and Law, 1(2), 60-63.

Zopiatis, A., Constanti, P., \& Theocharous, A. (2014). Migrant labor in hospitality: The Cyprus experience. International Journal of Hospitality Management, $111-120$. http://dx.doi.org/10.1016/j.ijhm.2013.11.002

\section{Copyrights}

Copyright for this article is retained by the author(s), with first publication rights granted to the journal.

This is an open-access article distributed under the terms and conditions of the Creative Commons Attribution license (http://creativecommons.org/licenses/by/3.0/). 